\title{
GROWTH, YIELD , QUALITY AND NUTRIENT UPTAKE OF POTATO (Solanum tuberosum, L.) AS AFFECTED BY TWO NITROGEN SOURCES APPLIED AT VARIOUS RATIOS \\ Khalil, A. A. \\ Soil, Water and Environment Res., Institute, Agric. Res. Center, Giza, Egypt
}

\begin{abstract}
A field experiment was carried out at the Experimental Res. Farm of El-Kassasin Horticultural Research Station, Ismailia Governorate, (Around $30^{\circ} .26^{\prime} \mathrm{N} 31^{\circ} 59^{\prime} \mathrm{E}$ ) during two successive seasons; 2009/2010 and 2010/2011 to study the effects of applying two different nitrogen sources ammonium sulphate (AS) and ammonium nitrate (AN), at the same rate of $140 \mathrm{~kg} \mathrm{Nfed}^{-1}$, and their ratios on growth, yield marketable, quality and nutrient uptake of potato (Solanum tuberosum L.; CV. Nicola). A completely randomized design was established with 5 treatments, i.e., (AS) / (AN) ratios of 100/0, 0/100,75/25, 50/50, 25/75 and. Each treatment had 3 replications. Representative samples were taken after 75 days and the yield was harvested after 120 days. Dry weights of tubers, at the harvest were increased significantly with all mixed nitrogen treatments as compared with single AS or AN. The enhanced growth with mixed nitrogen was greatest at $25 \%$ (AS) Ammonium Sulphate $+75 \%$ (AN) Ammonium Nitrate. Such treatment produced maximum dry matter $(24.20 \%)$, total yield $\left(13.765 \mathrm{~kg}_{\text {fed }}{ }^{-1}\right.$ ) and N,P and $\mathrm{k}$ uptake and marketable yield (\%86.6) followed by the treatment having $50 \%$ AS $+50 \%$ AN. Usage of $140 \mathrm{~kg} \mathrm{Nfed}^{-1}$ applied as a mixture of $25 \%$ AS $+75 \%$ AN achieved $17 \%$ and $11 \%$ increment of total yield compared to $100 \%$ of AS application and $100 \%$ AN, respectively.

The study stressed on paying attention to selection of sources of $\mathrm{N}$ fertilizers and their ratios for potato plants grown in sandy soil.

Keywords: potato (Solarium tuberosum L.),nutrient uptake, Dry matter, N sources, Ammonium sulphate to ammonium nitrate ratio, Marketable yield.
\end{abstract}

\section{INTRODUCTION}

Potato (Solanum tuberosum, L.) is one of the most important world food crops.it comes after rice, wheat and maize. Among vegetable crops being planted in Egypt, potato occupies higher rank in terms of exportation and local consumption. It is consumed in different forms such as boiled or fried and many different processed products like chips, french fries, flakes, powder, potato papad etc. Quality attributes of potato tubers particularly size, dry matter, starch and sugar contents are of prime concern for potato growers, in order to attain good prices for their produce (Pandey and Sarkar, 2005; Pandey et al., 2009). Nitrogen fertilization is a key factor for potato quality processing, besides its influence on potato size preferred for fresh consumption.

Not only tuber size is affected by nitrogen but also by starch content and sugar content. Nitrogen as a major element being essential for plant growth, is available to plants in two forms namely nitrate nitrogen (NO3- $-\mathrm{N}$ ) and ammonium nitrogen (NH4+-N). Nitrogen forms affect plant growth and yield. Most plants get their nitrogen $(\mathrm{N})$ from the soil as either nitrate or ammonium, with some species showing a strong preference for one ionic 
form over the other (Forde and Clarkson, 1999). Nevertheless, plant growth decreases under excessive nitrogen supply. The growth of potato (Cao and Tibbtts, 1998) and bean (Sánchez et al., 2004), are significantly inhibited due to application of excessive nitrogen. In this regard Wei et al., 2009 reported that under high nitrogen levels, most plant species show reduced growth, smaller leaves and stunted root systems, and in severe cases can lead to death of the plant. High nitrate levels in soil or nutrient solution will cause osmotic stress, which can cause oxidative damage and induce reactive oxygen species (ROS). They are highly toxic and can damage many important cellular components, such as lipids, protein, DNA and RNA. Increased levels of ammonium could be highly toxic for plant cells (Pilbeam and Kirkby, 1992).

Usually plants are able to take up $\mathrm{N}$ as nitrate (NO3-) and ammonium $(\mathrm{NH} 4+)$, but some may prefer one source or another depending on plant species (Marschner, 1995). N sources may affect plant growth via many processes within the soil plant system, and inside the plant (Wiesler, 1997). The use of different $\mathrm{N}$ sources may directly affect the nutrition status of plants due to changes in the rhizosphere, as a result of modification in the ionic balance in that soil fraction. The use of $\mathrm{N}-\mathrm{NH} 4+$ causes an increasing $\mathrm{H}+$ excretion, leading to a decrease in soil $\mathrm{pH}$, whereas the use of N-NO3- is associated with a decrease in $\mathrm{H}+$ excretion and increasing rates of $\mathrm{HCO} 3$ - or $\mathrm{OH}$ - resulting in a pH rise, especially when in combination with $\mathrm{Ca} 2+$ (Marschner and Römheld, 1996). However, when plants are growing in a similar way and supplied with N-NO3- or $\mathrm{N}-\mathrm{NH} 4+$, they may differ in many aspects related to metabolic activity and ionic composition as a result of different physiological responses (Kandlbinder et al., 1997). The reduction of $\mathrm{N}-\mathrm{NO} 3-$ in plants consume great amount of reducing power. Considering the biochemical energy needed for NO3- reduction, one could suppose that plant supplied with $\mathrm{N}-\mathrm{NH} 4$ would grow better than that supplied with $\mathrm{N}-\mathrm{NO} 3-$ source, however in most cases the opposite occurs even altering the plant architecture of fast growing plants (Beltrano et al., 1999). Some species show growth depression when supplied exclusively with $\mathrm{N}-\mathrm{NH} 4+$, but generally this causes a decrease in soil $\mathrm{pH}$ which may increase the availability of some mineral nutrients such as $\mathrm{P}, \mathrm{Fe}, \mathrm{Mn}, \mathrm{Cu}$, and $\mathrm{Zn}$ (Marschner, 1995).

Improving the soil/plant relationship is depending on soil conditions. $\mathrm{N}$ transfer from roots to leaves can occur in different manners and its incorporation in different amino acids, proteins, and other $\mathrm{N}$ compounds are differentiated for each plant species and development stage (Pate, 1973). The aim of this research was to study the effects of applying two different nitrogen sources $A S$ and $A N$ and their ratios on growth, yield marketable, nutrient uptake (N,P and K) and quality of potato (Solanum tuberosum L.).

\section{MATERIALS AND METHODS}

A field experiment was carried out at the Experimental Res. Farm of ElKassasin Horticultural Research Station, Ismailia Governorate, (Around

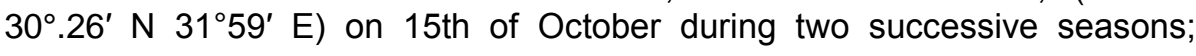


2009/2010 and 2010/2011 to study the effects of applying two different nitrogen sources $A S$ and $A N$ and their ratios on growth, yield marketable, quality and nutrient uptake ( $\mathrm{N}, \mathrm{P}$, and $\mathrm{K}$ ) of potato (Solanum tuberosum L.; CV. Nicola); grown under sprinkler irrigation. Some Physical and chemical characteristics for the soil under study were conducted according to (Page et al., 1982) and (Klute, 1986). The results are shown in table 1

Table 1: Some physical and chemical properties of the studied soil.

\begin{tabular}{|c|c|c|c|c|c|c|c|c|c|}
\hline \multicolumn{6}{|c|}{ Particle size distribution (\%) } & \multirow{3}{*}{$\begin{array}{c}\text { Textural } \\
\text { class }\end{array}$} & \multirow{2}{*}{\multicolumn{2}{|c|}{$\mathrm{Ca} \mathrm{CO}_{3}(\%)$}} & \multirow{3}{*}{ O.M (\%) } \\
\hline \multirow{3}{*}{\multicolumn{2}{|c|}{\begin{tabular}{|c|}
$\begin{array}{c}\text { Coarse } \\
\text { sand }\end{array}$ \\
2.38 \\
\end{tabular}}} & \multirow{3}{*}{\multicolumn{2}{|c|}{\begin{tabular}{|c|} 
Fine sand \\
67.42
\end{tabular}}} & \multirow{3}{*}{$\begin{array}{r}\text { Silt } \\
18.2 \\
\end{array}$} & \multirow{3}{*}{$\begin{array}{l}\text { Clay } \\
12.00 \\
\end{array}$} & & & & \\
\hline & & & & & & & & & \\
\hline & & & & & & Sar & & 2.1 & 0.8 \\
\hline \multirow[t]{2}{*}{$\mathrm{pH}$} & \multirow{2}{*}{$\begin{array}{c}E C \\
d S m^{-1}\end{array}$} & \multirow{2}{*}{ \%SP } & \multicolumn{5}{|c|}{$\begin{array}{l}\text { Ion concentration in paste extract } \\
\qquad\left(\mathrm{meqL}^{-1}\right)\end{array}$} & \multicolumn{2}{|c|}{$\begin{array}{c}\text { Available (mg } \\
\left.\mathrm{kg}^{-1}\right)\end{array}$} \\
\hline & & & \multicolumn{2}{|c|}{$\mathrm{Ca}^{++}\left|\mathrm{Mg}^{++}\right| \mathrm{I}$} & \begin{tabular}{l|l|l|}
$\mathrm{Na}^{+}$ & $\mathrm{K}^{+}$ & $\mathbf{C}$ \\
\end{tabular} & \begin{tabular}{|l|l|}
$\mathrm{HCO}_{3}^{-}$ & $\mathrm{Cl}^{-}$ \\
\end{tabular} & & $\mathbf{N}$ & $\mathbf{K}$ \\
\hline 2 & 0.87 & 29 & 3.90 & 2.70 & $1.85|0.55|$ & \begin{tabular}{l|l}
1.30 & 4 \\
\end{tabular} & & 25.4 & $0 \mid 180.5$ \\
\hline
\end{tabular}

The experiment was laid out in factorial design based on complete randomized block design with three replications. Experimental factors included two $\mathrm{N}$ sources ammonium sulfate (AS); $\mathrm{NH} 4$ (SO4)2 having $20.6 \%$ $\mathrm{N}$, and ammonium nitrate (AN), ( $\mathrm{NH} 4 \mathrm{NO} 3)$ having $(33.5 \% \mathrm{~N})$. The two $\mathrm{N}$ sources were applied at the same amount of $\mathrm{N}$ namely $140 \mathrm{~N} \mathrm{~kg} / \mathrm{fed}$. Five (AS) / (AN) ratio were used: 100/0, 0/100, 75/25, 50/50 and 25/75.The experimental treatments were as follow:-

$100 \% \mathrm{~N}$ as Ammonium Sulphate (AS).

$100 \% \mathrm{~N}$ as Ammonium Nitrate (AN).

$75 \%$ AS + $25 \%$ AN.

$50 \%$ AS $+50 \%$ AN.

$25 \%$ AS $+75 \%$ AN.

The tested nitrogenous fertilizers and their ratios were split into four doses and added at four stages namely; $20 \%$ before planting, $20 \%$ at plant establishment, $30 \%$ at tuber initiation and $30 \%$ at tuber bulking.

Phosphorus fertilizer was added at the recommended dose, $75 \mathrm{~kg} \mathrm{P} 2 \mathrm{O} 5 \mathrm{per}$ fed. However, $50 \%$ of the amount was applied to the soil in the form of calcium superphosphate (15.5\% P2O5) during soil preparation and the rest was fertigated in the form of phosphoric acid (62\% P2O5) split into equally dose during growth stages.

Potassium fertilizer was fertigated at a rate of $120 \mathrm{~kg} \mathrm{~K} 2 \mathrm{O}$ in the form of Potassium sulfate $(50 \% \mathrm{~K} 2 \mathrm{O})$ split into 5 equal doses, one at soil preparation and the rest at $35,45,55$ and 65 days after planting.

At 75 days after planting four plants were taken randomly form each plot to determine plant height $(\mathrm{cm})$ and number of main stems/plant.

Total tuber yield (kg.fed-1), and tuber weight/plant were determined at harvesting (120 days after planting).

$\mathrm{N}, \mathrm{P}$ and $\mathrm{K}$ were determined in the leaves at 75 days of planting and in tubers at harvesting time. Total nitrogen was determined in dry leaves and 
tubers using micro-kjeldahl methods as described by Ling (1963), while P was determined calorimetrically and potassium was determined by using a flame photometer as described by Jackson (1967).

Tuber Quality was appraised through testing some parameters namely; dry matter (\%), starch content, carbohydrate fractions and specific gravity of tubers besides grading their size.

Starch content was determined according to A. O. A. C. (1990) .Tuber dry matter (\%) was determined by drying the tuber slices at $65^{\circ} \mathrm{C}$ for 72 hours according to the method of A. O. A. C. (1990). Carbohydrate fractions were determined in tuber according to the method described by Miller (1959). Specific gravity; SG of tuber was estimated using following formula outlined by Murphy and Goven (1959);

$S G=$ (tuber weight in the air)/ ((tuber weight in the air) - (tuber weight in the water)

Tubers were graded according their size to large size $>55$, medium size; 35-55and small size; $<35 \mathrm{~mm}$ in diameter (Fattahalla, 1997). All collected data were statistically analyzed according to the procedure described by Snedecor and Cochran (1980). The statistical analysis was conducted for all yield parameters of the two seasons i.e. combined analysis.

\section{RESULTS AND DISCUSSION}

Effects of N-Sources and their ratios on the growth of potatoes plants:

Data in Table 2 show the effect of using different sources of nitrogen and various ratios of them on plant height and number of stems per plant ; average means of both seasons. Data elucidate that plant height was significantly elevated as the plants received $25 \% \mathrm{AS}+75 \% \mathrm{AN}$ compared with the other treatments.

The shorter plant height $(49.2 \mathrm{~cm})$ was recorded when $100 \%$ (AS) was administered and no significant difference was observed in the plant height recorded for such treatment and that of $75 \%$ AS+25\%AN. Nevertheless, the longest plant height $(64.5 \mathrm{~cm})$ was recorded with the application of $25 \%$ AS $+75 \%$ AN.

Table 2: Effects of N-Sources and their ratio on the growth of potatoes plants. (average means of both seasons.)

\begin{tabular}{|c|c|c|}
\hline N Sources and their ratios & Plant height cm & $\begin{array}{c}\text { Mean No. of } \\
\text { stems/plant }\end{array}$ \\
\hline $100 \%$ Ammonium Sulphate (AS) & $49.2 \mathrm{~d}$ & 2.75 \\
\hline $100 \%$ Ammonium Nitrate (AN) & $52.9 \mathrm{c}$ & 2.75 \\
\hline $75 \%$ AS+25\%AN & $50.9 \mathrm{~d}$ & 2.80 \\
\hline $50 \%$ AS+50\%AN & $55.9 \mathrm{~b}$ & 3.20 \\
\hline $25 \%$ AS $+75 \%$ AN & $64.5 \mathrm{a}$ & 3.70 \\
\hline LSD 0.05 & 1.99 & N.S \\
\hline
\end{tabular}


The data reveal that the lowest number of stems per plant $(2.75 \mathrm{~cm})$ was assigned for the plants received sole nitrogen source while plants received $25 \% \mathrm{AS}+75 \%$ AN gave the highest number of stems per plant (3.7). This parameter is of great importance because it is directly related to the total production of tubers. The more is the number of stems/plant the more is the number of tubers per plant. Number of stems per plant is also important for tuber size. (Marschner, 1986) pointed out that the increase in plant height may be attributed to the beneficial effects of $\mathrm{N}$ on stimulating the meristmatic activity for producing more tissues and organs and $\mathrm{N}$ plays major roles in structural proteins and other several macromolecules related with growth plants. Walch-Liu et al., (2000) reported that excessive NH4+ is harmful to tobacco plants and could result in hormonal imbalance and a strong decline of cytokinins in the xylem sap, which could then hamper growth and reduce yield.

The diverse response of plant to $\mathrm{N}-\mathrm{NO} 3$ and $\mathrm{N}-\mathrm{NH} 4$ was interpreted by some researchers. Romero et al., 2006) explained that applying N-NO3 may increase the plant highest, the acid-base balance that was broken, in which NO3- increased the $\mathrm{pH}$ around the roots due to the efflux of $\mathrm{HCO}$ - or $\mathrm{OH}$-, and $\mathrm{NH} 4+$ decrease the $\mathrm{pH}$ due to the efflux of $\mathrm{H}_{+}$

\section{Effect of $\mathrm{AS} / \mathrm{AN}^{-}$ratio on nutrients content in leaves and tubers}

Table 3 displays the effect of using different sources of $\mathrm{N}$-fertilizers on $\mathrm{N}$, $\mathrm{P}$ and $\mathrm{K}$ contents in leaves and tubers of potato. Nitrogen content in the leaves of potato exhibited remarkable difference due to diverse source of nitrogen and/or their combination. Application of $25 \%$ AS+75\% AN gave the highest $\mathrm{N} \%$ in the leaves (5.33\%). As the \% of added ammonium sulfate (AS) was increased $\mathrm{N}$ content of the leaves significantly decreased. It is worth mentioning that the lowest \% of $\mathrm{N}$ content was recorded in leaves of potato fertilized solely with AS (3.6\%). Interestingly similar trend was generally noticed in the case of $P$ and $k$ content in the leaves.

Higher concentration of $\mathrm{P}$, and $\mathrm{K}$ were recorded in treatments received $25 \% \mathrm{AS}+75 \% \mathrm{AN}$ of nitrogen, which in turn resulted in higher concentration of $\mathrm{P}$, and $\mathrm{K}$ in leaves. The highest percent of $\mathrm{P}(0.54)$ and $\mathrm{K}$ (4.09) were recorded with the application of nitrogen at $25 \% \mathrm{AS}+75 \%$ AN. These effects of $\mathrm{N}$ forms on tissue mineral composition were consistent with (Cao and Tibbtts, 1993).

Table 3: Effects of $\mathrm{N}$-Sources on $\mathrm{N}, \mathrm{P}$ and $\mathrm{K}$ content in potato plant. (average means of both seasons.)

\begin{tabular}{|c|c|c|c|c|c|c|c|c|c|}
\hline \multirow[t]{2}{*}{ Treatments } & \multicolumn{3}{|c|}{$\begin{array}{l}\text { Nutrients content in } \\
\text { leaves after } 75 \text { day }\end{array}$} & \multicolumn{3}{|c|}{$\begin{array}{l}\text { Nutrients content in } \\
\text { Tubers at harvest }\end{array}$} & \multicolumn{3}{|c|}{$\begin{array}{c}\text { Total uptake at harvest } \\
\mathrm{kg} / \mathrm{fed} .\end{array}$} \\
\hline & $\% \mathbf{N}$ & $\% \mathbf{P}$ & $\% \mathbf{K}$ & $\% \mathbf{N}$ & $\% \mathbf{P}$ & $\% \mathbf{K}$ & $\mathbf{N}$ & $\mathbf{P}$ & $\mathbf{K}$ \\
\hline $\begin{array}{c}100 \% \text { Ammonium } \\
\text { Sulphate (AS) }\end{array}$ & $3.6 \mathrm{e}$ & $0.34 \mathrm{~d}$ & $3.45 \mathrm{c}$ & $1.8 \mathrm{~b}$ & $0.28 \mathrm{~d}$ & $1.74 \mathrm{~d}$ & $207.9 \mathrm{~b}$ & $32.6 \mathrm{~d}$ & $198.4 \mathrm{~d}$ \\
\hline $\begin{array}{c}100 \% \text { Ammonium } \\
\text { Nitrate (AN) }\end{array}$ & $4.68 \mathrm{c}$ & $0.46 \mathrm{~b}$ & $3.61 \mathrm{~b}$ & $1.7 \mathrm{~b}$ & $0.39 \mathrm{~b}$ & $1.85 \mathrm{~b}$ & $1 \mathrm{~b}$ & 47 & $220.8 \mathrm{c}$ \\
\hline $75 \% A S+25 \%$ AN & $4.14 \mathrm{~d}$ & $0.39 \mathrm{c}$ & $3.68 \mathrm{~b}$ & $1.58 \mathrm{c}$ & $0.33 \mathrm{c}$ & $1.78 \mathrm{c}$ & $190.5 \mathrm{c}$ & $39.7 \mathrm{c}$ & $218.4 \mathrm{c}$ \\
\hline $50 \% A S+50 \%$ AN & $4.99 \mathrm{~b}$ & $0.49 \mathrm{~b}$ & $4.05 \mathrm{a}$ & $1.7 \mathrm{~b}$ & $0.42 \mathrm{~b}$ & $1.93 \mathrm{a}$ & $209.7 \mathrm{~b}$ & $50.75 \mathrm{~b}$ & $234.8 \mathrm{~b}$ \\
\hline $25 \% A S+75 \%$ AN & $5.33 \mathrm{a}$ & $0.54 \mathrm{a}$ & $4.09 \mathrm{a}$ & $2.05 \mathrm{a}$ & $0.45 \mathrm{a}$ & $1.97 \mathrm{a}$ & $283.6 \mathrm{a}$ & $61.6 \mathrm{a}$ & $271.1 \mathrm{a}$ \\
\hline LSD 0.05 & 0.185 & 0.042 & 0.12 & 0.097 & 0.035 & 0.046 & 9.57 & 4.35 & 6.92 \\
\hline
\end{tabular}


Effect of AS and AN ratio on Yield and marketable yield of potatoes:

Different AS and AN ratios significantly affected the size distribution of potatoes (Table 4). Regarding the size of potato the data clearly indicated that the source of $\mathrm{N}$ played indispensable role in obtaining desired marketable size. Applying 25 AS+ 75\% AN gave significantly bigger sizes; medium and large, compared with those obtained due to sole application of $100 \%$ AS and/or $100 \%$ AN. The opposite was true regarding the small size. The maximum yield of $13,766 \mathrm{~kg}$ fed.-1 was obtained in the treatment $25 \%$ AS $+75 \%$ AN followed by those receiving $75 \%$ AS $+25 \%$ AN $(12,219 \mathrm{~kg}$ fed. -1 and $50 \% A S+50 \%$ AN $(12,169 \mathrm{~kg}$-fed) .

Table 4:The effects of N-Sources on Tuber marketable yield and size distribution(average means of both seasons.)

\begin{tabular}{|c|c|c|c|c|c|c|c|c|c|}
\hline Treatments & $\begin{array}{l}\text { Yield } \\
\text { kg fed }^{-1} \\
\text { Small } \\
\text { size }^{*}\end{array}$ & $\begin{array}{c}\text { \% Yield } \\
\text { Small } \\
\text { size }\end{array}$ & $\begin{array}{l}\text { Yield } \\
\text { kg fed }^{-1} \\
\text { Medium }^{*} \text { size }^{\star \star}\end{array}$ & \begin{tabular}{|c|}
$\%$ \\
Medi \\
um \\
Yield
\end{tabular} & $\begin{array}{c}\text { Yield kg } \\
\text { fed }^{-} \\
{ }^{1} \text { Large }^{-} \\
\text {size }^{\star \star \star}\end{array}$ & $\begin{array}{c}\% \\
\text { Yield } \\
\text { Large } \\
\text { size }\end{array}$ & $\begin{array}{c}\% \\
\text { Marketable } \\
\text { size }\end{array}$ & $\begin{array}{c}\text { Total } \\
\text { Yield } \\
\text { kg fed }^{-1}\end{array}$ & $\begin{array}{c}\text { Total } \\
\text { Yield } \\
\text { kg/plant }\end{array}$ \\
\hline $\begin{array}{c}100 \% \\
\text { Ammonium } \\
\text { Sulphate (AS) }\end{array}$ & 2023 a & 17.8 & $9175 \mathrm{e}$ & 80.2 & $225 d$ & 2.0 & 82.2 & $11423 \mathrm{~d}$ & $0.887 \mathrm{c}$ \\
\hline $\begin{array}{c}100 \% \\
\text { Ammonium } \\
\text { Nitrate (AN) }\end{array}$ & 1912 b & 16.0 & 9787 c & 81.7 & $281 \mathrm{c}$ & 2.4 & 84.1 & $11981 \mathrm{c}$ & $0.958 \mathrm{~b}$ \\
\hline $75 \% A S+25 \% A N$ & $2065 \mathrm{a}$ & 17.4 & $9431 \mathrm{~d}$ & 80.0 & $723 \mathrm{~b}$ & 2.5 & 82.5 & $12219 \mathrm{~b}$ & $0.943 \mathrm{~b}$ \\
\hline $50 \% A S+50 \% A N$ & $1900 \mathrm{~b}$ & 14.6 & $10161 \mathrm{~b}$ & 82.2 & $108 \mathrm{e}$ & 3.2 & 85.2 & $12169 \mathrm{~b}$ & $0.953 \mathrm{~b}$ \\
\hline $25 \% A S+75 \% A N$ & $1803 \mathrm{c}$ & 14.1 & $11203 \mathrm{a}$ & 83.5 & $750 \mathrm{a}$ & 3.1 & 86.6 & $13766 \mathrm{a}$ & $1.055 \mathrm{a}$ \\
\hline LSD 0.05 & 54.4 & & 66.87 & & 16.11 & & & 105.9 & 0.052 \\
\hline
\end{tabular}

${ }^{\star}$ small size;<35mm, ${ }^{* \star}$ medium size; $35-55,{ }^{\star \star *}$ large size; $>55$, Marketable; large +medium size

The yield was lowest (11.423 kg fed. -1$)$ in the treatment receiving $100 \%$ (AS). Usage of combination of $25 \% \mathrm{AS}+75 \% \mathrm{AN}$ achieved $17 \%$ and $11 \%$ increment of the total yield compared to $100 \%$ of AS application and $100 \%$ AN, respectively. But, it was only $9 \%$ with $75 \%$ AS $+25 \%$ AN and $8 \%$ with $50 \%$ AS+50\% AN. It is worthy to note that differences arise from diversity of the fertilizer prices of the studied $\mathrm{N}$ sources have no impact on the production cost of potato. The present results are in harmony with those reported by (Wang et al., 2009) who stressed the usage of mixed nitrogen sources for obtaining higher yield. Moreover, Cao and Tibbitts 1993 demonstrated that dry weights of shoots, tubers, and whole plant at the harvest were increased significantly with all mixed nitrogen treatments as compared with single $\mathrm{NH} 4+$ or NO3- form. The enhanced growth with mixed nitrogen was greatest at $8 \%$ to $20 \% \mathrm{NH} 4+-\mathrm{N}$. Also, the concentrations and accumulation of total $\mathrm{N}$ in the shoots and roots were greater with mixed nitrogen than with separate $\mathrm{NH} 4+$ or NO3- nutrition.

On the contrary (Ge, 2002; and Wang et al., 2005) reported that the highest yield of plant was produced at $0: 100$ of AS to AN.

In the current study higher sulphur content, present in the fertilizer applied seems to have a detrimental effect on the growth of potato. In this concern, many workers reported that although sulphur plays substantial role in potato production through its role in better partitioning of the photosynthates in the shoots and tubers, yet heavy application of sulphur can result in yield 
reduction (Sud and Sharma2002 and Lalitha et al. 2002). Their findings are in consonance with Nasreen et al. (2007) on onion.

Effect of nitrogen sources and their ratios on tubers quality of potato

Table 5 summarizes the results of the some quality tests done on potatoes grown under different treatments (average means of both seasons).

Table 5: The effects of $\mathrm{N}$-Sources and their ratios on qualitative characters of potato (average means of both seasons).

\begin{tabular}{|l|c|c|c|c|c|}
\hline Treatments & $\%$ NS Sugar & $\begin{array}{c}\text { \% Total } \\
\text { Sugar }\end{array}$ & \%D.M & $\begin{array}{c}\text { specific } \\
\text { gravity }\end{array}$ & \%Starch \\
\hline $\begin{array}{l}100 \% \text { Ammonium } \\
\text { Sulphate (AS) }\end{array}$ & $34.81 \mathrm{c}$ & $37.25 \mathrm{e}$ & $17.54 \mathrm{~d}$ & $1.052 \mathrm{e}$ & $14.62 \mathrm{e}$ \\
\hline $\begin{array}{l}100 \% \text { Ammonium } \\
\text { Nitrate (AN) }\end{array}$ & $33.22 \mathrm{~d}$ & $35.68 \mathrm{~d}$ & $22.35 \mathrm{~b}$ & $1.057 \mathrm{~d}$ & $15.93 \mathrm{~d}$ \\
\hline $75 \% \mathrm{AS}+25 \% \mathrm{AN}$ & $36.08 \mathrm{c}$ & $38.5 \mathrm{c}$ & $19.87 \mathrm{c}$ & $1.064 \mathrm{c}$ & $17.18 \mathrm{c}$ \\
\hline $50 \% \mathrm{AS}+50 \% \mathrm{AN}$ & $37.18 \mathrm{~b}$ & $39.69 \mathrm{~b}$ & $22.14 \mathrm{~b}$ & $1.073 \mathrm{~b}$ & $18.84 \mathrm{~b}$ \\
\hline $25 \% \mathrm{AS}+75 \% \mathrm{AN}$ & $40.82 \mathrm{a}$ & $43.50 \mathrm{a}$ & $24.14 \mathrm{a}$ & $1.082 \mathrm{a}$ & $20.75 \mathrm{a}$ \\
\hline LSD 0.05 & 0.72 & 0.74 & 1.04 & 0.0019 & 0.92 \\
\hline
\end{tabular}

Tubers quality, such as starch, specific gravity, D.M soluble sugar, non-soluble sugar and total sugar $\%$ were significantly $(P \leq 0.05)$ affected by AS and AN ratio. Starch, specific gravity, D.M. and total sugar \% differed significantly due to the studied $\mathrm{N}$ fertilization management. Regardless the effect of $100 \%$ of ammonium nitrate on the dry matter the assigned higher value recorded for these parameters followed the order:

$25 \%$ AS $+75 \%$ AN $>50 \%$ AS $+50 \%$ AN $>75 \% A S+25 \%$ AN $>100 \%$ (AN) $>100 \%$ (AS).

The obtained results concerning the effects of AS and AN ratio on Tubers quality of potato was in accordance with Dong et al. (2004) who reported that increasing the ratio of AS/AN (25, 50 and $75 \%)$ in the treatments led to a significant decrease in Starch, and D.M content.

The specific gravity is a measure of quality in potato tuber which is related to the dry matter contents in the tubers. The specific gravity is also associated with starch content, total solids and mealiness of potato tubers (Teich and Menzres 1964). They also reported a reduction in specific gravity due to fertilizer treatment and its influence on crop quality. The higher is the specific gravity the better is the quantity of dry matter and greater is the yield of produce. Potatoes with high specific gravity are preferred for manufactured processes.

(Lalitha et al, 2002) exeplained that sulphur being a component of sulphur containing amino acid as well as involved in sulpho-hydral bonds in polypeptides, also component of protein enzyme involved in chlorophyll, starch and protein synthesis. Involvement of sulphur in these biochemical processes in plant metabolism may be the cause for increased starch synthesis and production of large size tubers.

Based on the above mentioned information it may be concluded that application of $25 \% \mathrm{AS}+75 \% \mathrm{AN}$ gave the best quality under experimental trails. 


\section{CONCLUSIONS}

Different AS and AN ratios in treatments not only affected plant growth, but also affected yield marketable and tubers quality of potato. The maximum yield and quality of potato was obtained as $25 \%$ of $\mathrm{N}$ was added in the the form of ammonium sulphate and the other $75 \%$ in the form of ammonium nitrate. Nonetheless, the lowest yield and quality was recorded as potato was fertilized with $100 \%$ Ammonium sulphate. This research drew the attention to the usage appropriate ratio of ammonium sulphate to ammonium nitrate for potato fertilization grown in Egypt rather than relying on sole source of them. Besides extra care should be given to higher content of sulphate in fertilization management of potato as higher content of such element could reduce its yield. More researches are needed to be carried out concerning such topic.

\section{REFERENCES}

A.O.A.C. (1990). Official Methods of Analysis. $15^{\text {th }}$ Ed. Washington DC, USA. Beltrano, J.; Ronco, M. G.; Barreiro, R. and Montaldi, E. R. (1999), Plant architecture of Paspalum vaginatum Schwartz modified by nitrate and ammonium nutrition, Pesquisa Agropecuária Brasileira, 34, 1159-1166

Cao, W. and Tibbitts, T.W. (1993). Study of various NH4+/NO3- mixtures for enhancing growth of potatoes. Journal of Plant Nutrition. Sep; 16(9):1691-704.

Cao W.X, and Tibbitts, T.W. (1998). Response of potatoes to nitrogen concentrations differ with nitrogen forms. J. Plant Nutr. 21: 615-623.

Chapman, H. D. and P.F. Pratt, (1961). Methods of Analysis for Soils, Plant and Waters. Univ. of California, Div.Agric. Sci., 60.

Dong, C.X., Shen, Q.R. and Wang, G. (2004). Tomato growth and organic acid changes in response to partial replacement of $\mathrm{NO}^{-}{ }^{-} \mathrm{N}$ by NH4 +N. Pedosphere. 14(2): 159-164.

Eddins, A.H., 1934. Effect of inoculated sulphur, lime and mercury compounds on the yield of potatoes. Am. J. Potato Res., 11: 295-302.

Fattahalla, M.A. (1997). Performance evaluation of some potato cultivars under the conditions of the new reclaimed land in Egypt .Zagazig J.Agric. Res., 24: 769-784.

Forde ,B.G. and Clarkson, D.T. (1999). Nitrate and ammonium nutrition of plants: physiological and molecular perspectives. Adv. Bot. Res. 30: 190.

Ge, X.G. (2002). Vegetable garden soil and fertilization Agriculture Press of China, Beijing. p. 212.

Jackson, M.L., (1967). Soil Chemical Analysis. Prentice-Hall, India, pp: 144197.

Kandlbinder, A.; Cruz, C. and Kaiser, W. M. (1997), Response of primary plant metabolism to the $\mathrm{N}$ source. Z. Pflanzenernähr. Bodenk., 160, 269-274.

Klute, A. (1986). Methods of Soil Analysis: part I. physical and mineralogical method ( $2^{\text {nd }}$ Ed.) Amer. Soc. Agron. Monograph No. 9. Madison-Wisconsin. USA. 
Ling, E. R. (1963).Determination of total nitrogen by semi micro- kjeldahl method. Dairy Chem., 11:23-84.

Lalitha, B.S., K.H. Nagaraj and T.N. Anand, 2002. Effect of source propagation, level of potassium and sulphur on potato (Solanum tuberosum L.). Mys. J. Agric. Sci., 36: 148-153.

Marschner, H. (1986). Mineral Nutrition in Higher Plants. Academic Press, Harcount Barace, Javonovish Publisher, pp.674

Marschner, H. 1995. Mineral nutrition of higher plants. $2^{\text {nd }}$ ed. Academic Press, London, UK. pp. 229_242.

Marschner H. and V. Römheld. 1996. Root-induced changes in the availability of micronutrients in the rhizosphere. p. 557-579. In $\mathrm{Y}$. Waisel, A. Eshel and U. Kafkafi, eds., Plant Roots: The Hidden Half. M. Dekker: New York.

Miller, G. L. (1959).Use of dinitrosalicylic acid reagent for determination of reducing sugars. Anal.Chem.; 31:426-428.

Murphy,H.G.and M.J.Goven (1959). Factors affecting the specific gravity of white potato in Main. Main Agric.Exp.Stat Bull.583.

Nasreen, S., M.M. Haque, M.A. Hossam and A.T.M. Fand, 2007. Nutrient uptake and yield of onion as influenced by nitrogen and sulphur fertilization. Bangladesh J. Agric. Res., 32: 413-420.

Page, A. L.; R. H. Miller and D. R. Keeny (1982). "Methods of Soil Analysis" part II. Chemical and microbiological properties $\left(2^{\text {nd }} E d\right.$.) Amer. Soc. Agron. Monograph No. 9. Madison-Wisconsin, USA.

Pandey, S.K. and Sarkar D. (2005) Potato in Indian emerging trend challenges in the new millennium. Potato J., 32: 93-104.

Pandey, S.K.; Marwaha R.S.; Kumar D.and Singh S.V. (2009). Indian potato processing story: Industrial limitation, challenges ahead and vision for the future. Potato J., 36: 1-13.

Pate, J. S. (1973), Uptake, assimilation and transport of nitrogen compounds by plants. Soil Biol. Biochem., 5, 109-119.

Pilbeam DJ.and Kirkby EA. (1992). Some aspects of the utilization of nitrate and ammonium by plants. In: Mengel K, Pilbeam DJ (Eds.), Nitrogen Metabolism of Plants. Clarendon Press, Oxford pp. 55-70.

Romero, F.R, Taber, H.G.and Gladon, R.J. (2006). Nitrogen source and concentration affect growth and performance of bedding-plant impatiens. J. Plant Nutr. 29: 1315-1326.

Sánchez E.; Rivero RM.; Ruiz JM. and Romero L. (2004). Changes in biomass, enzymatic activity and protein concentration in roots and leaves of green bean plants (Phaseolus vulgaris L. cv. Strike) under high NH4NO3 application rates. Sci. Hortic. 99: 237-248.

Snedecor, W.G. and G.W. Cochran, (1980). Statistical Methods. 17th Ed., lawa State Univ. Press, Ames,USA., pp: 50.

Sud, K.C. and R.C. Sharma, 2002. Sulphur needs of potato under rainfed conditions in Shimla hills. In: Potato Global Research and Development, Khurana, S.M.P, G.S. Shekhawat, S.K. Pandey and B.P. Singh (Eds.). Vol.2. Indian Potato Association, Shimla, pp: 889899. 
Teich, A.H. and J.A. Menzres. (1964). NPK on specific gravity, ascorbic acid, and chipping quality of potato tubers. Am. Potato J., 41: 169-173.

Walch-Liu, P., Neumann, G.; Bangerth, F. and Engels, C. (2000). Rapid effects of nitrogen form on leaf morphogenesis in tobacco. J. Exp. Bot. 51:227-237.

Wang J.; Sun Xx, Shen Q, and Zhou, Y. (2005). Effects of some Replacement of nitrate by ammonium on the biomass yield and quality of spinach. Soil, 37(6): 605-608

Wang, J.; Zhou, Y., Dong,C.; Shen,Q.and Putheti,R.(2009). Effects of NH4 +$\mathrm{N} / \mathrm{NO} 3$--N ratios on growth, nitrate uptake and organic acid levels of spinach (Spinaciaoleracea L.). African Journal of Biotechnology ,8 (15), pp. 3597-3602.

Wei GP.; Yang LF.; Zhu YL.and Chen G. (2009). Changes in oxidative damage, antioxidant enzyme activities and polyamine contents in leaves of grafted and non-grafted eggplant seedlings under stress by excess of calcium nitrate. Sci. Hortic. 120: 443-451

Wiesler, F. (1997), Agronomical and physiological aspects of ammonium and nitrate nutrition of plants.Z. Pflanzenernähr. Bodenk., 160, 227-238.

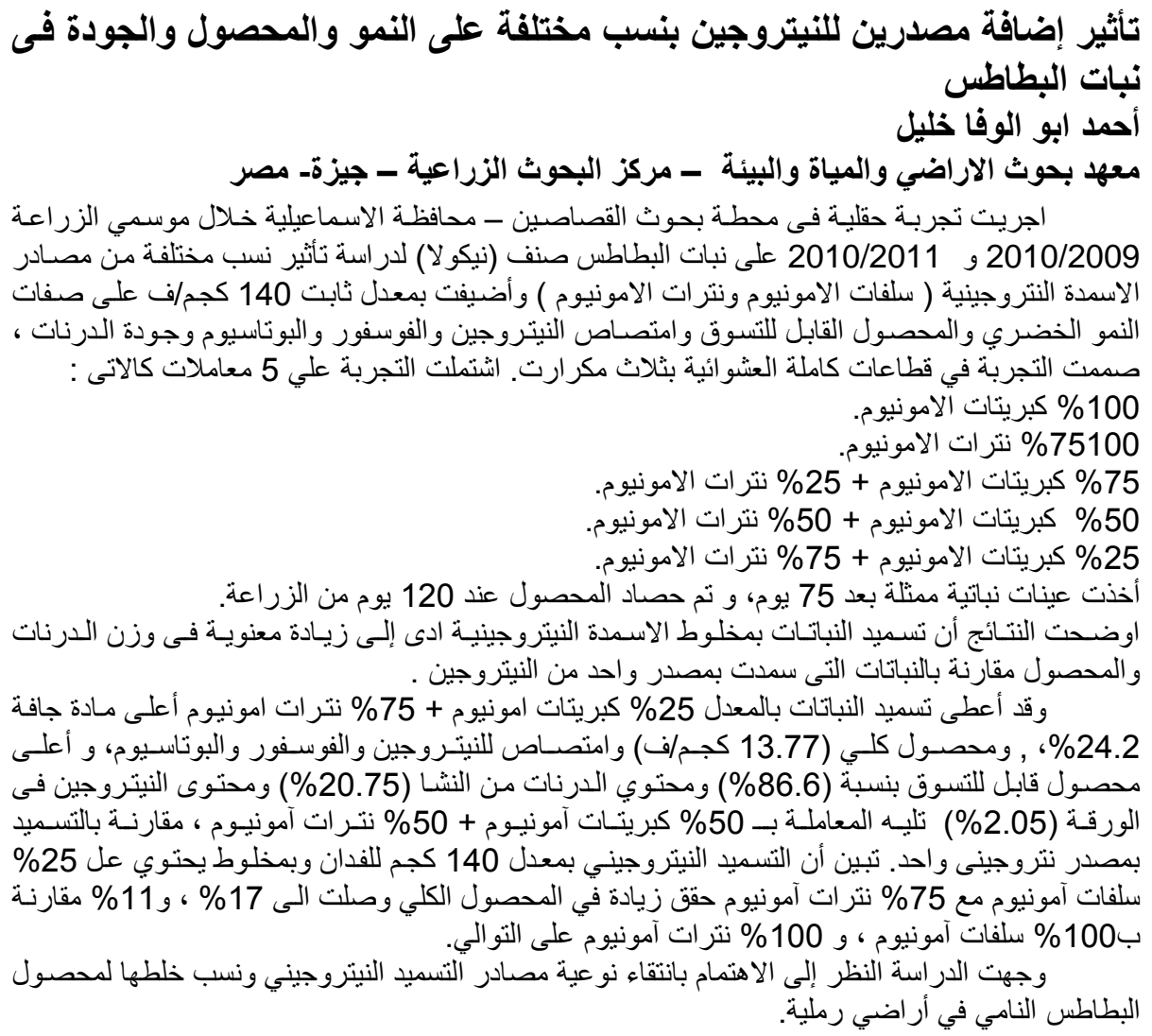

